\title{
Olfactory Receptor 51B4
}

National Cancer Institute

\section{Source}

National Cancer Institute. Olfactory Receptor 51B4. NCI Thesaurus. Code C134690.

Olfactory receptor 51B4 (310 aa, $~ 35 \mathrm{kDa}$ ) is encoded by the human OR51B4 gene. This protein is involved in G protein-coupled receptor-mediated signaling following exposure to odorant molecules. 